\title{
Pre-Service Teacher Education and Technology Integration amid COVID-19 Pandemic in Colleges of Education
}

\author{
Dr. Aina, Jacob Kola ${ }^{1}$, Ayodele, Michael Olu ${ }^{2}$, Aremu Rauf Adekunle ${ }^{3}$ \\ School of Science Education. Kwara State College of Education (Tech.), Lafaigi, Nigeria
}

\begin{abstract}
The paper focuses on integrating technologies for instruction in pre-service teacher education during the COVID19 pandemic in Nigerian Colleges of Education. The emergence of COVID-19 occasioned the shifting paradigm of teaching in schools worldwide to online methods. The script discussed that pre-service teachers in Nigerian Colleges of Education is facing the challenge of integrating technologies into classroom instruction. The article stressed the importance of ICT to achieve quality pre-service teacher education in Colleges of Education. Integrating technologies into pre-service teacher education and the challenges COVID-19 poses to pre-service teacher education was discussed. The author averred that mobile learning through WhatsApp, Facebook, YouTube, and Google Classroom during the COVID-19 would provide sustained education. The conclusion was that teachers and students should explore mobile learning's full benefits through WhatsApp Instant Messaging, Facebook, YouTube, and Google Classroom during the pandemic.
\end{abstract}

Keywords: COVID-19, social distancing, technology, mobile learning, Google Classroom.

\section{INTRODUCTION}

$\mathrm{C}$ olleges of education are tertiary institutions that specialize in the training of professional teachers in Nigeria. The College of Education's educational program duration is three years, and the certificate awarded after passing prescribed exams is the Nigerian Certificate in Education (NCCE, 2012; Adetayo, 2016). The College of Education programs' objective is to produce teachers who will teach at the primary school and the basic junior secondary schools (Akindutire \& Ekundayo, 2012; Oritsebemigho, 2014). The National Commission for Colleges of Education (NCCE) is by law responsible for coordinating these colleges' academic programs. Most teachers in Nigerian schools are the products of these colleges. However, in the last three decades, teachers' cohorts cannot meet the $21^{\text {st }}$-century teaching requirement due to gaps in the teacher education program. Critical among these gaps is the challenge of the integration of technologies into classroom instruction.

Integrating ICT globally into teaching and learning remains the key to sound education in all learning institutions (Nordin, Davis \& Ariffin, 2013). Lawal and Braimoh (2018) observed some gaps in teacher education in Nigeria; one of these is the lack of ICT knowledge to personalize the curriculum and help support trainees for problem-solving activities.
Quality teacher is fundamental to quality education (Aina \& Olanipekun, 2015). However, studies show teachers should integrate technologies into teaching in the 21st century for effective teaching and learning (Abdalla \& Ali, 2017). For teachers to be successful in their careers, it was argued that such teachers must evolve themselves in pedagogy, content, and technology knowledge (Sahin, 2011).

Integrating technologies into teaching has many benefits for teachers and students (Gur \& Karamete, 2015). It helps students to create interest in learning (Sahin, 2011). It enables the teacher to change how they think about teaching (Gur \& Karamete, 2015). However, studies indicate that many schools are yet to use these advantages (Kafyulilo, Fisser, Pieters, \& Voogt, 2015). Empirical studies show that many Nigerian teachers' knowledge is indigent in using computers in the classroom (Aina \& Olanipekun, 2018). Countries like Tanzania have made ICT use in their educational system a matter of policy (Kafyulilo, Fisser, Pieters, \& Voogt, 2015). Despite the availability and accessibility of computers in many schools, particularly in Nigeria, most teachers do not use them to teach (Hosseini \& Kamal, 2013). The emergence of the COVID-19 pandemic had further exposed the technology's challenge in the pre-service teacher education in the country's educational system. COVID-19 caused disruptions to the world system; according to Drake and Reid (2020), this includes teachers and students.

The emergence of the COVID-19 pandemic had devastating impacts on Nigeria's global educational system. The pandemic's effect is alarming on the nation's educational system (Sahu, 2020). Social distancing has been considered adequate to curb the virus's spread (Blocken, Malizia, van Druenen \& Marchal, 2020). Social distancing is a step taken to reduce physical contact with other individuals (European Centre for Disease Prevention and Control, 2020). During this period, as a social distancing measure, students and teachers cannot interact in groups. Schools are closed down for many weeks; thus, teaching and learning are disrupted (UNESCO, 2020). Teaching and learning are done remotely using different technologies without prior preparation (Figg, Lu, Lu $\&$ Crawford, 2020). Most countries shifted teaching and learning to different virtual modes. According to Radha, Mahalakshmi, Kumar, and Saravanakumar (2020), the COVID-19 pandemic crisis makes it mandatory for schools 
globally to switch to e-learning. However, most developing countries, including Nigeria, could not adequately use this paradigm because of many factors, mostly the teacher education gap previously explained. According to Subedi, Nayaju, Shah, and Shah (2020), the technological, education/literacy background, and socioeconomic challenges are significant issues in developing countries.

\section{TECHNOLOGY IN PRE-SERVICE TEACHER EDUCATION}

Pre-service teacher education in the $21^{\text {st }}$ century is evolving to include ICT in the preparation of teachers. Davis (2010) cited in Nordin, Davis, and Ariffin (2013) that teachers' preparation in New Zealand and many countries include ICT to enhance teaching and learning. Bhakta and Dutta (2016) observed the significance of technology in education because traditional teaching and learning methods were replaced with new emerging technologies. It is, therefore, critical to ensure that technology occupies a central position in teacher preparation. Teachers are the essential variable for the teaching and learning process (Aina \& Olanipekun, 2015) and should be vast in using technologies to teach. Therefore, technology should form part of the pre-service teacher education program. Sahin (2011) said the ICT knowledge would allow the teachers to develop in all areas of their professional job.

Technologies in pre-service teacher education in the $21^{\text {st }}$ century are essential to producing sound critical thinking skills (Sahin, 2011). Teacher Education College in Tanzania was equipped with computers to prepare teachers who can integrate technology into classroom teaching (Kafyulilo, Fisser \&Voogt, 2015). Many other countries did the same, but it is worrisome that most pre-service teachers are indigent in integrating technologies into teaching. The primary factor responsible for this may not be unconnected with the previous studies, which show that most teachers in colleges have a poor attitude towards ICT (Sánchez, Marcos \& GuanLin, 2012; Aina \& Ogundele, 2014; Al-Zaidiyeen, Mei \& Fook, 2020). Technology in education is sure to be an area of change that has been challenging (McQuirter, 2020).

Technologies integration in the classroom has many benefits for both the teachers and the students. Previous studies before the emergence of the COVID-19 pandemic confirmed that the integration of technologies in the school is significant to the quality of education (Ibara, 2014; Ghavifekr \& Rosdy, 2015; Kilinc, Kilinc, Kaya, Başer, Türküresin \& Kesten, 2016; AlZaidiyeen, Mei \& Fook, 2010).

Integration of technologies into the classroom in pre-service education programs is challenging because the resources are not available. Tools for learning such as Weblog, Wiki, podcasting, instant messaging, social bookmarking, text chat, RSS, and internet forums (Pande, Wadhai, \& Thakare, 2016) are wrongly utilized. Several digital devices are available for pre-service teachers, but internet connectivity limits these devices' operation for effective teaching and learning. Given this, Trucano (2014) observed that Nigeria's underdeveloped broadband infrastructure poses a challenge to e-learning in schools. Therefore, the issue of technologies in pre-service teacher education had severe implications on Colleges of Education during the COVID-19 lockdown in Nigeria.

\section{THE CHALLENGE COVID-19 POSES TO PRE- SERVICE TEACHER EDUCATION}

The emergence of COVID-19 came with unexpected challenges to the entire world. Universities and colleges were closed for an extended period because of international and national lockdown. Teaching and learning were disrupted because of social and physical distancing. However, many advanced countries shifted from conventional teaching to various types of e-learning with the aids of digital technologies. The outbreak of COVID-19 suddenly changed educators, parents, and students' orientation to the use of technologies for teaching and learning (Fackler \& Sexton, 2020). The new paradigm had a different level of success in countries worldwide because the teachers and students are technology savvy. Contrarily, most developing nations had challenges in shifting paradigms because of the problems earlier discussed. According to Wu, Pearce, and Price (2020), the shifting to online instruction has posed multiple challenges for teachers (educators). One of the challenges of shifting instruction during COVID-19 is students' inability to interact physically with peers and teachers (Vasquenz, 2020).

Interaction in learning is supported by the social constructivism theory (SCT). The theory of social constructivism firmly believes that students create knowledge as they interact with teachers and peers. According to Schreiber and Valle (2013), Vygotsky, who is a proponent of social constructivism, submitted that learning is a social and collaborative task where learners create meaning as they interact. Interaction is essential to learning: thus, Educause Learning Initiative (2005) opined that it should be linked to interaction for learning to be successful. Education remains a process of interaction that allows the learners to develop their understandings by assembling facts, experiences, and practices. According to Kim (2001), through interactions, learners create meaning in learning contexts related to each other.

Most Colleges of Education in Nigeria had drawbacks in their academic calendars. The emergence of the COVID-19 pandemic has provided the opportunity to examine education (Mindzak, 2020), especially the pre-service teacher education. Teaching practice (practicum) programs were adversely affected. Pre-service science teacher education programs were affected severely because teaching and learning of science was difficult due to experiments' involvement. Many teachers and students possess mobile digital devices that could be explored at this time, but they could not because of inadequate knowledge.

The period of COVID-19 lockdown was challenging in the history of Colleges of Education in Nigeria. Few teachers adopted teaching through WhatsApp messaging, YouTube, 
and Facebook but, many students could not cope because students do not use the Apps for educational purposes before the COVID-19 pandemic (Aina \& Olanipekun, 2018). On several occasions, students have challenges in downloading lecture materials: images, graphics, and video. The outbreak of COVID-19 strengthens the inequality in education among pre-service teachers. Because the government could not provide quality e-learning for these students at this critical time: only those from wealthy backgrounds can meet the cost of this type of learning. The world is brazing up for the second wave of COVID-19. It thus implies stakeholders in preservice teacher education should be proactive to ensure quality teacher education is sustained.

\section{SUSTAINING TEACHER EDUCATION DURING AND AFTER THE COVID-19 PANDEMIC}

Quality teacher education is not negotiable with or without the COVID-19 pandemic because quality teacher is critical to the world economy's sustainability. According to Adhikary (2018), a quality teacher who is an active user of ICT for teaching is indispensable to any quality teaching and learning process. Therefore, both in-service teachers and pre-service must be technology savvy. Bingimlas (2018) considered technological expertise as the general knowledge of technologies, such as software, smart devices, and social media, which require specific skills to operate. In light of this, the teacher's Technological Pedagogical Content Knowledge (TPACK) is imperative. TPACK framework represents teacher knowledge of technology integration in teaching (Barisic, Divjak \& Kirinic, 2017). During the COVID-19 pandemic, e-learning remains the best strategy to teach and learn; however, it will be difficult if the teacher's TPACK is inadequate. According to Nordin, Davis \& Ariffin (2013), the TPACK provides a model to guide the effective integration of ICT into teaching. Teachers could explore different online learning strategies during the COVID-19 lockdown for preservice teachers but could not because of inadequate TPACK.

Mobile learning (m-learning) is an example of online learning that could be explored during COVID-19 lockdown. During the last lockdown, most students and teachers possessed good mobile phones, tablets, and iPad, yet they could not deploy them for fruitful educational purposes. Most of these devices contain Apps for educational purposes. These Apps are WhatsApp, YouTube, Facebook, Twitter, and others.

Mobile technologies enhance learning where access to education is not feasible, such as the COVID-19 time (Mehdipour \& Zerehkafi, 2013). It is portable, convenient, affordable, which both teachers and students could explore to promote teaching and learning (Aina \& Olanipekun, 2018; Sarrb, Elgamel, \& Aldabbas, 2012). M-learning is convenient because it is accessible virtually anywhere: it provides access to all the different learning materials (Alsaadat, 2017).

WhatsApp allows the user to send information as text, image, video, and voice messages depending on their knowledge (Aina et al. 2018). WhatsApp is typically used by students in schools as a means of instant communication. Table 1 shows an example of how the University's student uses WhatsApp for different academic purposes.

Table 1. Distribution of the University students' uses of WhatsApp for educational purposes.

\begin{tabular}{|c|c|c|c|c|}
\hline $\mathrm{S} / \mathrm{N}$ & Purpose & $\begin{array}{c}\text { Daily } \\
(\%)\end{array}$ & $\begin{array}{c}\text { Weekly } \\
(\%)\end{array}$ & $\begin{array}{c}\text { Monthly } \\
(\%)\end{array}$ \\
\hline 1 & $\begin{array}{c}\text { Communicate classmate on } \\
\text { courses requirement }\end{array}$ & 39.6 & 22.7 & 18.2 \\
\hline 2 & $\begin{array}{c}\text { Communicate instructor on } \\
\text { courses requirement }\end{array}$ & 10.4 & 19.5 & 19.5 \\
\hline 3 & Publish courses announcements & 22.7 & 18.8 & 16.2 \\
\hline 4 & $\begin{array}{c}\text { Discuss with instructor on } \\
\text { courses related issues }\end{array}$ & 23.4 & 17.5 & 20.8 \\
\hline 5 & $\begin{array}{c}\text { Seek help from old students on } \\
\text { courses requirement }\end{array}$ & 26.6 & 16.2 & 26 \\
\hline 6 & $\begin{array}{c}\text { Post links related to topics and } \\
\text { resources on courses }\end{array}$ & 23.4 & 14.9 & 24 \\
\hline 7 & $\begin{array}{c}\text { Formation of students groups for } \\
\text { education purpose }\end{array}$ & 24.7 & 22.7 & 18.2 \\
\hline 8 & $\begin{array}{c}\text { Organize meetings with } \\
\text { classmates on assignment \& } \\
\text { project }\end{array}$ & 21.4 & 16.9 & 20.8 \\
\hline 9 & $\begin{array}{c}\text { Get feedback from course } \\
\text { instructors }\end{array}$ & 21.4 & 16.9 & 20.8 \\
\hline 10 & Organize time of study & 26 & 16.9 & 12.3 \\
\hline 11 & $\begin{array}{c}\text { Discuss ideas with classmates on } \\
\text { course-related issue }\end{array}$ & 24 & 22.1 & 20.8 \\
\hline
\end{tabular}

Source: Al-Mothana (2017)

Facebook is a tool utilized to promote academic practices in the advanced world (Ligi \& Raja, 2017). Facebook becomes an interesting subject among researchers, and several studies were published (Capua, 2012). Stakeholders in education should use WhatsApp in schools during the COVID-19 for learning instead of entertainment. Video is a learning tool in schools supported and influenced by YouTube (Tamim, 2013). The use of YouTube in mobile learning promotes authentic learning, which is absent in many classrooms (Aina et al., 2018).

At this critical time in the global history of education, it's time to incorporate these Apps to the pre-service teacher education program in developing countries like Nigeria. Adopting this learning mode is cost-effective because almost all students have mobile learning devices; they could learn anytime and anywhere. One good advantage of this paradigm of learning is that it allows students to reflect on their learning tasks. Reflection is one essential element of authentic learning, allowing students to revisit learning tasks at any time (Herrington, Reeves \& Oliver, 2010). The students can replay the recorded audio lectures or replay the videos several times for comprehension. Figure 1 conceptualized mobile learning using WhatsApp Instant Messaging, Facebook, and YouTube

Figure 1 shows that the exploration of m-learning through the WhatsApp Instant Messaging, Facebook, and YouTube promote collaboration and reflection in learning. Collaboration is critical to teaching and learning (Har, 2013). Collaboration would be vital at this period of the pandemic for 
both teachers and students. Therefore, stakeholders in education should make fair use of WhatsApp Instant Messaging, Facebook, and YouTube at this critical period. Besides, many students are familiar with searches on Google but not familiar with Google Apps for Education.

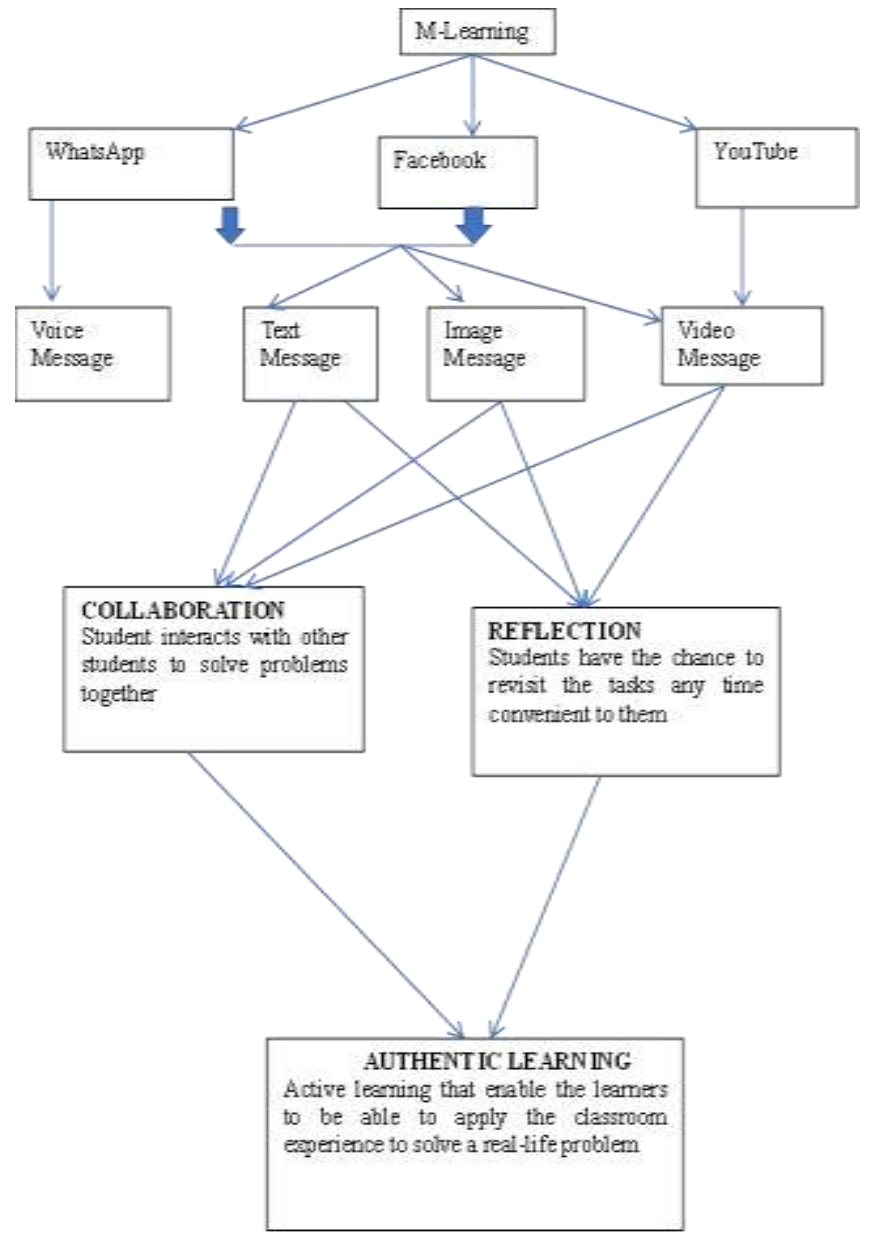

Figure 1: mobile learning conceptual framework (Aina et al., 2018)

Google Classroom is a Google Apps for Education, assisting teachers in creating and organizing assignments quickly, providing efficient feedback, and efficiently communicating with their learners (Shaharanee, Jamil \& Rodzi, 2016). The application is used as an e-learning mode (Henukh, Rosdianto \& Oikawa, 2020). Several earlier studies show that the Google Classroom helps students learn more electronically, and teachers spend more quality time with students than with papers (Basher, 2017; Rabbi, Zakaria \& Tonmoy, 2018). As an emerging technology in education since 2014, Google Classroom had impacted teaching and learning in most nations (Shaharanee, Jamil \& Rodzi, 2016; Basher, 2017; Rabbi, Zakaria \& Tonmoy, 2018; Henukh, Rosdianto \& Oikawa, 2020).

During this period, the e-learning is the best because it does not necessarily involve physical contact between the teacher and the students (Trucano, 2014). The modes of e-learning could be adjunct and blended e-learning (Arkorful \& Abaidoo,
2014). One of the Blended learning mode is Enrich virtual (Eastman, 2015; Bryan \& Volchenkova, 2016). Other methods used face-to-face classroom learning with the ICT and online instructions that are not the best during the COVID-19 crisis because of physical distance. The Enrich virtual is more of internet instructions and would be the best for this period. The Google Classroom is a purely online mode that could be in the category of the Enrich virtual.

Many authors opined that Google Classroom promotes learning because it has no geographical limitation (Mafa, 2018; Henukh \& Rosdianto, Oikawa, 2020). According to Azhar and Iqbal (2018), Google Classroom is one significant way technology impacts teaching and learning worldwide when launched in 2014. Therefore, literature suggests the online learning like Google Classroom, which does not depend on traditional paradigms, is imperative. The Google Classroom framework would bridge the existing inequality in education (Mohamedbhai, 2014). The classroom context of the Google Classroom is the same for all categories of students.

Given this, teaching and learning will be better and comfortable during the COVID-19 if schools adopt the Google Classroom framework. However, the challenge of poor internet connectivity may hamper its success in many African countries like Nigeria. According to Ajadi, Salawu, and Adeoye (2008), bandwidth is a significant problem associated with e-learning.

\section{CONCLUSION}

Technology in the pre-service teacher education is essential during the COVID-19 pandemic because of the social distancing, which prohibits physical contact. Due to the emergence of the COVID-19, there is a shift in the paradigm of instructions to online strategies. The article argued that ICT is critical to the teacher education program for the success of the online teaching methods. However, the author identified a gap in technology integration in the pre-service teacher education program in Nigerian Colleges of Education. The paper reviewed previous studies on the significance of teachers' ICT knowledge at this pandemic period, making the teacher's TPACK critical.

The script highlighted a few benefits of integrating technologies to teaching, learning and the challenge of teachers' poor attitude toward ICT in Colleges of Education. Besides, the article discussed the challenges COVID-19 poses to teacher education. To achieve sustainable teacher education, the author discussed mobile learning's imperative using WhatsApp Instant Messaging, Facebook, and YouTube to promote collaboration and reflection in learning. Finally, the Google Classroom as a Google Apps is an Enrich blended method capable of sustaining teaching and learning during the COVID-19. Therefore, teachers and students should explore mobile learning's full benefits through WhatsApp Instant Messaging, Facebook, YouTube, and Google Classroom during the pandemic. 


\section{REFERENCES}

[1] Abdalla, A. M., \& Ali, M. A. A. I. (2017). EFL teachers' technological pedagogical content knowledge (TPACK): Practical perspectives. Red Sea University Journal Human Science, 4(2017), 7-38

[2] Adetayo, J. O. (2016). Teachers' factors as determinants of the professional competence of the Nigeria certificate in education (NCE) teachers. Journal of Education and Practice, 7(20), 1-11.

[3] Adhikary, M. C. (2018). Role of teachers in quality enhancement education and human development. International Journal of Humanities and Social Science Invention (IJHSSI), 7(12), 34-41

[4] Aina, J. K., \& Ogundele, A. G. (2014). The use of Technology for Teaching and Learning in Science and Technical Education in Colleges of Education, Nigeria. Integrated Journal of British, 1(3), 57-64.

[5] Aina, J. K., \& Olanipekun, S.S. (2015). A review of teacher selfefficacy, pedagogical content knowledge (PCK) and out-of-field teaching: Focusing on Nigerian teachers. International Journal of Elementary Education, 4(3), 80-85.

[6] Aina, J.K., Olanipekun, S.S. (2018). Mobile-Learning (MLearning) through WhatsApp Messaging, Facebook, and YouTube, Nigeria. Education Journal, 1(4), 111-121. DOI: 10.31058/j.edu.2018.13008

[7] Ajadi, T. O., Salawu, I. O., \& Adeoye F. A. (2008). E-learning and distance education in Nigeria.The Turkish Online Journal of Educational Technology, 7(4), 1-10

[8] Akindutire, I.O., \& Ekundayo, H.T. (2012). Teacher education in a democratic Nigeria: Challenges and the way forward. Educational Research, 3(5), 429-435.

[9] Al-Mothana, G. (2017).University students' use of WhatsApp and their perceptions regarding its possible integration into their education. Global Journal of Computer Science and Technology: G Interdisciplinary, 17(1), 1-11

[10] Alsaadat, K. (2017). Mobile learning technologies. International Journal of Electrical and Computer Engineering (IJECE), 7(5), 2833-2837

[11] Al-Zaidiyeen, N. J., Mei, L. L., \& Fook, F. S. (2010). Teachers' attitudes and levels of technology use in classrooms: the case of Jordan schools. International Education Studies, 3(2), 211-218.

[12] Arkorful, V., \& Abaidoo, N. (2014). The role of e-learning, the advantages and disadvantages of its adoption in Higher Education. International Journal of Education and Research, 2(12), 397-410

[13] Azhar, K. A., \& Iqbal, N. (2018). Effectiveness of Google classroom: teachers' perceptions. Prizren Social Science Journal, 2(2), 52-66

[14] Babatunde, M. L., \& Braimoh, D. S. (2018). The Nigerian teacher education industry: Gaps, challenges and prospects. International Journal of Arts Humanities and Social Sciences Studies, 3(1), 4756.

[15] Barisic, K.D, Divjak B., \& Kirinic, V (2017). Validation of survey of pre-service teachers' knowledge of teaching and technology in the context of Croatian educational system Retrieved August 27, 2018, from http://archive.ceciis.foi.hr/app/public/conferences/2017/02/CECIIS -2017_paper_6_final.pdf.

[16] Bingimlas, K. (2018). Investigating the level of teachers' knowledge in technology, pedagogy, and content (TPACK) in Saudi Arabia. South African Journal of Education, 38(3), 1-12

[17] Blocken, B., Malizia, F., van Druenen, T., \& Marchal, T. (n.d). Towards aerodynamically equivalent COVID19 $1.5 \mathrm{~m}$ social distancing for walking and running. Retrieved April 16, 2020, fromhttp://www.urbanphysics.net/Social\%20Distancing\%20v20_ White_Paper.pdf.

[18] Bhakta, K., \& Dutta, N. (2016). Impact of information technology on teaching-learning process. International Research Journal of Interdisciplinary \& Multidisciplinary Studies (IRJIMS), 2(11), $131-138$
[19] Bryan, A., \& Volchenkova, K. N. (2016). Blended learning: Definition, models, implications For higher education. Education Educational Sciences, 8 (2), 24-30. DOI: 10.14529/ped160204

[20] Capua, I. D. (2012). A literature review of research on Facebook use. The Open Communication Journal, 6(2012), 37-42

[21] Drake, S. M., \& Reid, J. (2020). How education shape a new story in a post-pandemic world. Brock Education Journal, 29(2), 6-12.

[22] Eastman, P. (2015). Blended learning: Design Guideline. Retrieved May 08, 2020, from http://oasis.col.org/bitstream/handle/11599/3095/2018_ClevelandInnes-Wilton_Guide-to-BlendedLearning.pdf?sequence $=1$ \&isAllowed $=y$

[23] Educause Learning Initiative (2005). Interaction: Principles and practice. ELI summer session. Retrieved January 12, 2021, from https://library.educause.edu/resources/2005/1/interactionprinciples-and-practice-eli-summer-session-2005

[24] European Centre for Disease Prevention and Control (2020). Considerations relating to social distancing measures in response to the COVID-19 epidemic. Stockholm: ECDC.

[25] Fackler, A. K., Sexton, C. M. (2020). Science teacher education in the time of covid-19: A document analysis. Electronic Journal for Research in Science \& Mathematics Education 24 (3), 5-13

[26] Figg, C., Lu, C., Lu, O., \& Crawford, K. (2020). E-3Cs: A research-based model for effective digital learning for K-6 schools. Brock Education Journal, 29(2), 24-29

[27] Ghavifekr, S., \& Rosdy, W. A. W (2015). Teaching and learning with technology: Effectiveness of ICT integration in schools. International Journal of Research in Education and Science (IJRES), 1(2), 175-191.

[28] Gür, H., \& Karamete, A. (2015). A short review of TPACK for teacher education. Educational Research and Reviews, 10(7), 777789.

[29] Har, L.B. (2013). Authentic learning. The Hong Kong Institute of Education. Retrieved from http://www.ied.edu.hk/aclass/

[30] Herrington, J., Reeves, T. C., \& Oliver, R. (2010). A guide to authentic e-learning. New York: Routledge

[31] Hosseini, Z., \& Kamal, A. (2013). A survey on pre-service and inservice on teachers' perceptions of technological pedagogical content knowledge (TPACK). The Malaysian Online Journal of Educational Technology, 1(2), 1-7

[32] Ibara, E. C. (2014). Information and Communication Technology Integration in the Nigerian Education System: Policy Considerations and Strategies. Educational Planning, 21(3), 5-18.

[33] Kafyulilo, A., Fisser, P., Pieters, J., \& Voogt, J. (2015). ICT use in science and mathematics teacher education in Tanzania: Developing Technological Pedagogical Content Knowledge. Australasian Journal of Educational Technology, 31(4), 381-399. DOI: $10.14742 /$ ajet.1240

[34] Kilinc, E., Kilinc, S., Kaya, M. M., Başer, E. H., Türküresin H. E., \& Kesten, A. (2016). Teachers' attitudes toward the use of technology in social studies teaching. Research in Social Science and Technology, 1(1), 59- 76.

[35] Kim, B. (2001). Social constructivism. In M. Orey (Ed), Emerging perspectives on learning, Teaching and technology. Retrieved from http://www.coe.uga.edu/epltt/Social Constructivism.htm.

[36] Ligi, B., \& Raja, B.W.D. (2017). Mobile learning in higher education. International Journal of Research - Granthaalayah, 5(4), 1-6. https://doi.org/10.5281/zenodo.569363.

[37] Mafa K. R. (2018). Capabilities of google classroom as a teaching and learning tool in higher education. International Journal of Science Technology \& Engineering, 5(5), 30-34

[38] McQuirter, R. (2020). Lesson on change: Shifting to online learning during COVID-19. Brock Education Journal, 29(2), 4751.

[39] Mehdipour, Y., \& Zerehkafi, H. (2013). Mobile learning for education: Benefits and challenges. International Journal of Computational Engineering Research, 3(6), 93-101.

[40] Mindzak, M. (2020). COVID-19 and the ongoing problem of educational efficacy. Brock Education Journal, 29(2), 18-23

[41] Mohamedbhai, G. (2020). COVID-19: What consequences for higher education? Retrieved April 23, 2020, from 
https://www.universityworldnews.com/post.php?story=202004070 64850279

[42] National Commission for Colleges of Education [NCCE] (2012) Nigeria certificate in education minimum standards for general education. Abuja, Nigeria: Author

[43] Nordin, H., Davis, N., \& Ariffin, T. F. T. (2013). A case study of secondary pre-service teachers' technological pedagogical and content knowledge mastery Level. Procedia - Social and Behavioral Sciences 103(2013) 1-9

[44] Oritsebemigho, T. O. (2014). An appraisal of the revised Nigeria certificate in education minimum standards (English language curriculum). European Scientific Journal, Special Edition, 165171

[45] Pande, D., Wadhai, V. M., \& Thakare, V. M. (2016). E-learning system and higher education. International Journal of Computer Science and Mobile Computing, 5(2), 274- 280

[46] Radha, R., Mahalakshmi, K., Kumar, V. S., \& Saravanakumar, A. R. (2020). E-learning during lockdown of Covid-19 pandemic: A global perspective. International Journal of Control and Automation 13(4), 1088-1099.

[47] Sahin, I. (2011). Development of survey of technological pedagogical and content knowledge (TPACK). TOJET: The Turkish Online Journal of Educational Technology, 10(1), 97-105

[48] Sahu P (April 04, 2020). Closure of universities due to coronavirus disease 2019 (COVID-19): Impact on education and mental health of students and academic staff. Cureus 12(4), 1- 6. e7541. DOI $10.7759 /$ cureus.7541

[49] Sarrab, M., Elgamel, L., \& Aldabbas, H. (2012). Mobile learning (M-learning) and educational environments. International Journal of Parallel Emergent and Distributed Systems, 3(4), 31-38
[50] Sánchez, A., Marcos, J. M., González, M., \& GuanLin, H. (2012). In-service teachers' attitudes towards the use of ICT in the classroom. Procedia - Social and Behavioral Sciences 46 (2012) $1358-1364$

[51] Schreiber, L.M., \& Valle, B.E. (2013). Social constructivist teaching strategies in the small group classroom. Small Group Research 44(4) 395-411.

[52] Subedi, S., Nayaju, S., Subedi, S., Shah, S. K., \& Shah, J. M. (2020). Impact of e-learning during COVID-19 pandemic among nursing students and teachers of Nepal. International Journal of Science and Healthcare Research, 5(3), 68-76.

[53] Tamim, R.M. (2013). Teachers' Use of YouTube in the United Arab Emirates: An exploratory study, computers in the schools. Interdisciplinary Journal of Practice, Theory, and Applied Research, 30(4), 329-345, DOI: 10.1080/07380569.2013.844641

[54] Trucano, M. (2014). Education and Technology in age of Pandemics (revisited). Revised April 23, 2020, from https://www.universityworldnews.com/post.php?story=202004091 50034920

[55] UNESCO (2020). COVID-19 Educational Disruption and Response. Retrieved 13 April, 2020, from https://en.unesco.org/covid19/educationresponse

[56] Vasquenz, S. (2020). Developing an online learning environment for community college students enrolled in human anatomy \& physiology and microbiology courses amid the COVID-19 pandemic. . Electronic Journal for Research in Science \& Mathematics Education 24(3), 53-59

[57] Wu, S. C., Pearce, E., \& Price, J. C. (2020). Creating virtual engagement for pre-service teachers in a science methods course in response to the covid-19 pandemic. Electronic Journal for Research in Science \& Mathematics Education 24(3), 38-44. 